\title{
THE INFLUENCE OF INCREASED PROTEIN CONTENT IN THE DIET ON RENAL FUNCTIONS IN CALVES
}

\author{
W. F. SKRZYPCZAK. M. OZGO. K. JANUS. E. SKOTNICKA. D. JANKOWIAK, \\ Z. MUSZCZYŃSKI, J. SUSZYCKA \\ University of Agriculture, Department of Animal Physiology, \\ ul. Doktora Judyma 6, 71-466 Szczecin. Poland \\ Received November 20, 1995 \\ Accepted June 6. 1996
}

\begin{abstract}
Skrzypczak W.F.. M. Ozgo, K. Janus. E. Skotnicka, D. Jankowiak, Z. Muszczyński. J. Suszycka: The Influence of Increased Protein Content in the Diet on Renal Functions in Calves. Acta vet. Brno 1996. 65:115-121.

The aim of this work was to study the effect of feeding calves in the neonatal period a diet with increased protein content on their renal function.

The experiment was carried out in 3 phases on 10 clinically healthy black and white calses. The diet fed to calves in phase 2 was enriched with 25\% casein compared to standard diet fed in phases I and 3 .

Studies on kidney functions in calves were perfomed using clearance methods in phase 1 , further 7 and 14 days after introducing phase 2, and 7 days after return to standard diet (phase 3 ), using inulin and PAH (para-aminohippuric sodium salt) as testing substances.

Glomerular filtration rate (GFR) and PAH clearance (ERPF Effective Renal Plasma Flow) were defined on the basis of inulin and PAH elimination rate from blood. Effective renal blood flow (ERBF) and filtration fraction (FF) were also calculated. Additionally the blood plasma electrolyte concentrations ( $\mathrm{Na}, \mathrm{K} . \mathrm{Cl}$ ), total protein content and urea concentration were also determined.

Increased protein amount in the diet did not affect the total protein and urea concentration in plasma. At the same time. the $\mathrm{Na}^{+}$concentration increased and the $\mathrm{K}^{+}$concentration decreased.

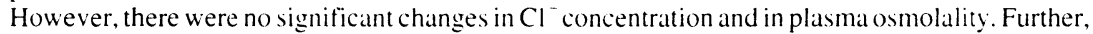
an increase of renal blood and plasma flow, increase of glomerular filtration rate (GFR) and filtration fraction were observed. These changes were statistically significant $(P<0.0) \mid$ ).

The results show that intake of a protein-rich diet modifies the renal functions in calves during their early postnatal period. Seven-day long period of feeding the animals a diet with casein supplement caused the renal blood and plasma flow to increase, and FF was higher. too. One may presume that it was the expression of mobilizing the adaptation mechanisms to effectively remove protein metabolism products from the organism. Renal hemodynamics changes induced by the protein-rich diet involved first of all the glomerular area as a prerequisite for plasma hyperfiltration.
\end{abstract}

Casein, diet, GFR. ERBF, FF, blood $\mathrm{Na}^{+}, \mathrm{K}^{+}, \mathrm{Cl}$, blood flow

Studies on the possibility of metabolic modification of renal function have been carried out with varied intensity since 1931. J o 11 i f e and S mith (1931) showed in man that the intake of animal protein increased glomerular filtration rate measured by inulin clearance 2 hours after its consumption. B e rg st ro m et al. (1985) observed in man that diet containing $2 \mathrm{~g}$ of protein $/ \mathrm{kg}$ of body mass causes a significant increase of inulin, endogenous creatinine and PAH clearances. B osh et al. (1983) proved that independently on the initial protein content in a diet, every additional protein supply causes a rapid rise of creatinine clearance in man. Nahoa et al. (1990) observed a compensatory growth of kidness after a highprotein diet and they presume that growth hormone and insulin-dependent growth factor (IGF-I) may be involved in this process.

No data on farm animals concerning issues presented in this paper have been found in the literature. Studies on high-protein diet influence on renal activity have been carried out so far mainly in laboratory animals and in man. Objective of this paper is to find whether feeding calves a diet with increased protein content affects their renal functions. 


\section{Materials and Methods}

The experiment was carried out on 10 clinically healthy calves of black and white breed. During the experiment the animals were kept in the following environmental conditions: ambient temperature of 18 " $\mathrm{C}$, relative humidity $70 \%$, L:D cycle was 16:8.

The experiment was conducted in three phases. During the first phase (till day 7 of life) the calves were fed full milk ( 81 per day with 280 g protein) prepared with powdered full milk. For the next two weeks, i.e. between days 7 and 21 (second phase: phase 2A - till day 14; phase 2B -till day 21) the diet was enriched w th casein in the amount equal to $25 \%$ of total protein content in a standard diet $(350 \mathrm{~g}$ protein per day) with unchanged amounts of carbohydrates and fat. During the third phase (days 21-28) the calves again received the same standard diet like during the phase 1 of the experiment.

Studies on renal functions were perfomed using the clearance methods in calves fed standard diet (phase 1). 7 and 14 days after introducing the protein-rich diet (phase $2 \mathrm{~A}$ and $2 \mathrm{~B}$ ). and 7 days after return to standard diet (phase 3), using inulin and ( $\mathrm{PAH}$ - para-aminohippuric acid sodium salt as testing substances.

Before the experiment began. the calves were weighed and the jugular external vein was catheterized. The clearance measurements always started at the same time of the day (at noon).

From the external jugular vein. "()" (blank sample) of blood was taken. and PAH and inulin concentration were determined. Heparin (250 I.U. Heparinum-Polfa) was used as anticoagulant agent. The calves were then given intravenously' sterile solution containing $40 \mathrm{mg} \cdot \mathrm{kg}^{-1}$ body mass of PAH and $40 \mathrm{mg} \cdot \mathrm{kg}^{-1}$ hody mass of inulin. Blood samples were taken 20,40 and 60 minutes after injections of inulin and PAH.

The blood samples were analysed to determine:

- inulin concentration (resorcin method - by Higashi and Peters 1970):

- PAH concentration (Brun's method - by Wang h and Beall 1974);

- hematocrit:

- osmolality (Knauer Osmometer. Germany).

Additionally, the blood plasma electrolyte concentrations ( $\mathrm{Na}$. K - flame photometry method, $\mathrm{Cl}$ - potentiometric titration method). total protein content (biuret method) and urea concentration (diacetylmonooxym methodBreinek and Bouda 1970) were also determined.

Glomerular filtration rate (GFR) and PAH clearance (ERPF - Effective Renal Plasma Flow) were defined on the basis of inulin and PAH elimination rate from blood. according to indirect Bettge's method ( $\mathrm{Skrzypczak}$ et al. 1989). Effective renal blood flow (ERBF) and filtration fraction (FF) were also calculated.

The results were standardized to $1 \mathrm{~m}^{2}$ of the calves' body surface and evaluated statistically using analysis of variance and Duncan's test.

\section{Results and Discussion}

The results obtained in the experiment are summarized in Tables 1 and 2.

In calves receiving the standard diet (phase 1 of the experiment), the tested parameters did not differ from the results obtained by us in previous experiments (S k r y p c zak 1989a, 1989b) and from other data found in literature (W anner et al. 1981: Hartmann et al. 1987). Effective renal blood and plasma flow were $383.87 \mathrm{ml} / \mathrm{min} / \mathrm{m}^{2}$ and $244.08 \mathrm{ml} / \mathrm{min} / \mathrm{m}^{2}$, respectively.

Glomerular filtration rate was $51.45 \mathrm{ml} / \mathrm{min} / \mathrm{m}^{2}$ and filtration fraction was 0.22 (Tab. 1). Average concentrations of electrolytes in plasma were: $\mathrm{Na}=120.7 \mathrm{mmol} / \mathrm{l}, \mathrm{K}=4.91$ $\mathrm{mmol} / \mathrm{l}, \mathrm{Cl}=96.9 \mathrm{mmol} / \mathrm{l}$, respectively. Plasma osmolality was $272.7 \mathrm{mmol} / \mathrm{kg} \mathrm{H} \mathrm{H}_{2} \mathrm{O}$ (Tab. 2 ). These values are within the physiological range. Total protein content and urea concentration in plasma were also within the physiological level and they were $66.3 \mathrm{~g} / \mathrm{l}$ and $3.24 \mathrm{mmol} / \mathrm{l}$, respectively (Tab. 1).

The increase of protein amount in the ration did not influence significantly the total protein and urea concentration in plasma. The levels of these components in plasma after 7 days of feeding the protein-rich diet were $66.33 \mathrm{~g} / \mathrm{l}$ and $3.17 \mathrm{mmol} / \mathrm{l}$, respectively (Tab. 1). At the same time the sodium concentration increased and the potassium concentration decreased. However, there were no significant changes in chloride concentration and in plasma osmolality (Tab. 2).

Enriching the diet with protein caused an increase of renal blood and plasma flow, increase 
Table 1

Renal function parameters and total protein and urea level in the blood of calves $(n=10, \bar{x} \pm S D)$

\begin{tabular}{|c|c|c|c|c|}
\hline \multirow{3}{*}{$\begin{array}{l}\text { Examined } \\
\text { Parameters }\end{array}$} & \multicolumn{4}{|c|}{ Phase of Experiment } \\
\hline & \multirow{2}{*}{1} & \multicolumn{2}{|c|}{2} & \multirow{2}{*}{3} \\
\hline & & A & B & \\
\hline $\begin{array}{l}\text { GFR } \\
\left(\mathrm{ml} / \mathrm{min} / \mathrm{m}^{2}\right)\end{array}$ & $\begin{array}{r}51.45 \\
5.67\end{array}$ & $\begin{array}{c}\# \\
74.14 \\
6.89\end{array}$ & $\begin{array}{c}70.36 \\
6.12\end{array}$ & $\begin{array}{r}57.95 \\
5.34\end{array}$ \\
\hline $\begin{array}{l}\text { ERPF } \\
\left(\mathrm{ml} / \mathrm{min} / \mathrm{m}^{2}\right)\end{array}$ & $\begin{array}{r}244.08 \\
53.90\end{array}$ & $\begin{array}{c}{ }_{285.71}^{\#} \\
56.89\end{array}$ & $\begin{array}{r}253.41 \\
52.11\end{array}$ & $\begin{array}{c}\text { \#, \$. \& } \\
200.86 \\
58.78\end{array}$ \\
\hline $\begin{array}{l}\text { ERBF } \\
\left(\mathrm{ml} / \mathrm{min} / \mathrm{m}^{2}\right)\end{array}$ & $\begin{array}{r}383.87 \\
74.89\end{array}$ & $\begin{array}{c}\# \\
447.54 \\
72.98\end{array}$ & $\begin{array}{r}404.27 \\
72.34\end{array}$ & $\begin{array}{c}\text { \#, \$, \& } \\
314.66 \\
79.23\end{array}$ \\
\hline $\mathrm{FF}(1 / 1)$ & $\begin{array}{l}0.22 \\
0.05\end{array}$ & $\begin{array}{l}{ }^{\#} \\
0.27 \\
0.05\end{array}$ & $\begin{array}{l}0.28 \\
0.04\end{array}$ & $\begin{array}{l}\text { \# } \\
0.30 \\
0.05\end{array}$ \\
\hline $\begin{array}{l}\text { Protein } \\
(\mathrm{g} / \mathrm{l})\end{array}$ & $\begin{array}{r}66.30 \\
6.01\end{array}$ & $\begin{array}{r}66.33 \\
6.11\end{array}$ & $\begin{array}{r}67.30 \\
5.90\end{array}$ & $\begin{array}{r}66.40 \\
5.34\end{array}$ \\
\hline $\begin{array}{l}\text { Urea } \\
\text { (mmol/l) }\end{array}$ & $\begin{array}{l}3.24 \\
0.29\end{array}$ & $\begin{array}{l}3.17 \\
0.23\end{array}$ & $\begin{array}{l}3.31 \\
0.32\end{array}$ & $\begin{array}{l}3.21 \\
0.30\end{array}$ \\
\hline
\end{tabular}

Notes :

A.B - fed diet with protein supplement

A - after 7 days of high-protein diet

B - after 14 days of high-protein diet

$\#$ - significantly different $(P \leq 0.01)$ from phase $1, \$-$ from phase $2 A, \&$ - from phase $2 B$

$\mathrm{GFR}=$ glomerular filtration rate

$E R P F=$ effective renal plasma flow

$E R B F=$ effective renal blood flow

$\mathrm{FF}=$ filtration fraction

Table 2

Concentrations of electrolytes and osmolality of plasma in examined calves $(n=10, \bar{x} \pm S D)$

\begin{tabular}{|c|c|c|c|c|}
\hline \multirow{3}{*}{$\begin{array}{l}\text { Examined } \\
\text { Parameters }\end{array}$} & \multicolumn{4}{|c|}{ Phase of Experiment } \\
\hline & \multirow{2}{*}{1} & \multicolumn{2}{|c|}{2} & \multirow{2}{*}{3} \\
\hline & & A & B & \\
\hline $\mathrm{Na}(\mathrm{mmol} / \mathrm{h})$ & $\begin{array}{r}120.7 \\
4.7\end{array}$ & $\begin{array}{c}127.9 \\
7.3\end{array}$ & $\begin{array}{c}129.4 \\
4.4\end{array}$ & $\begin{array}{c}\# \\
131.1 \\
6.4\end{array}$ \\
\hline $\mathrm{K}(\mathrm{mmol} / \mathrm{l})$ & $\begin{array}{l}4.91 \\
0.53\end{array}$ & $\begin{array}{r}\# \\
4.72 \\
0.36\end{array}$ & $\begin{array}{l}\text { \#. S } \\
4.46 \\
0.54\end{array}$ & $\begin{array}{l}\quad \# . \$ \\
4.35 \\
0.39\end{array}$ \\
\hline $\mathrm{Cl}(\mathrm{mmol} / \mathrm{l})$ & $\begin{array}{r}96.9 \\
5.6\end{array}$ & $\begin{array}{r}96.5 \\
4.4\end{array}$ & $\begin{array}{r}96.2 \\
3.9\end{array}$ & $\begin{array}{r}96.0 \\
3.4\end{array}$ \\
\hline $\begin{array}{l}\text { Osmolality } \\
\text { mosmol/kg } \mathrm{H}_{2} \mathrm{O}\end{array}$ & $\begin{array}{r}272.7 \\
8.4\end{array}$ & $\begin{array}{r}272.8 \\
7.4\end{array}$ & $\begin{array}{r}269.7 \\
12.5\end{array}$ & $\begin{array}{r}273.5 \\
6.3\end{array}$ \\
\hline
\end{tabular}

Notes:

A.B - fed diet with protein supplement

A- after 7 days of high-protein diet

$\mathrm{B}$ - after 14 days of high-protein diet

$\#$ - significantly different $(P \leq 0.01)$ from phase $1, \$$ - from phase $2 A . \&$ - from phase $2 B$ 
of glomerular filtration rate (GFR) and filtration fraction (Tab. 1). These changes were statistically significant $(\mathrm{P}<0.01)$.

After two weeks of feeding the protein-rich diet, a decrease of renal blood and plasma flow and later its stabilization on the initial level were found (Tab. 1). These changes were statistically significant. However, the glomerular filtration rate value decreased only insignificantly to $70.36 \mathrm{ml} / \mathrm{min} / \mathrm{m}^{2}$. This level tended to be definitely higher than in the first phase of the experiment (Tab. 1). Filtration fraction was maintained on a high level (0.28).

Total protein content and urea concentration in plasma did not show significant changes in the third phase of the experiment compared with the first and second ones (Tab. 1).

Further increase of sodium concentration in plasma was observed. Also a decrease of potassium concentration was noticed. Chloride concentration and plasma osmolality did not change significantly (Tab. 2)

In the third phase of the experiment. 7 days after feeding the standard diet. a significant decrease of renal blood and plasma flow was noticed to values lower than those observed in the first phase of the experiment (Tab. 1). At the same time GFR decreased to the value 57.95 $\mathrm{ml} / \mathrm{min} / \mathrm{m}^{2}$. This value was higher than that observed in the first phase of the studies (Tab. 1). Filtration fraction was high (0.30) (Tab. 1).

The results show that intake of the protein-rich diet strongly modifies the renal functions in calves during their early postnatal period. Seven-day long period of feeding the animals a ration with casein supplement caused the renal blood and plasma flow to increase. Filtration fraction was higher, too. One may presume that it was the expression of mobilizing the adaptive mechanisms in order to remove protein metabolism products effectively from the organism. Kidney hyperfusion and plasma hyperfiltration in glomeruli confirm the results obtained by other authors in studies on man or laboratory animals (Brenner 1983: Graf 1983; Alvestrand et al. 1988, Lee and Summerill 1992). The results obtained in this experiment indicate that a protein-rich diet does change the hemodynamic conditions in the kidneys, mainly in glomerular area, making them favourable to filtration processes. It seems that the ERBF value changed more dynamically in response to organism's internal environmental changes than other tested parameters of renal functions.

It is interesting that the effective renal blood flow became stabilized at the initial level after 14 days of feeding the protein-rich diet while the glomerular filtration rate was high throughout the whole period under study. It indicates undoubtedly changes of hemodynamics in glomeruli caused probably by elevation of effective filtration pressure.

In our opinion. this phenomenon can be explained by Alvestrand and Bergstrom (1984) hypothesis assuming that the increase (induced by larger protein amount in a ration) of free amino acids flowing to liver stimulates the liver to produce a hormone. This hormone (glomerulopressin) is a glucuronide, isolated from blood ultrafiltrate of the hepatic vein (B one t to et al. 1987; Maggior a et al. 1991). Glomerulopressin administered into the artery of an isolated kidney increases blood flow and glomerular filtration rate by reducing muscular tone of afferent glomerular arteriole, probably with direct or indirect participation of renal prostaglandins (Alvestrand et al. 1988; Maggiora et al. 1991). Graf 's (1983) studies also confirm this hypothesis on the base of a similar reaction of kidneys to systemic intravenous infusion of amino acids. In Alvestrand and Bergstrom 's experiments the increase in ERBF and GFR after adminstration of a solution of amino acids directly into the renal artery was not noticed.

Perhaps another mechanism is involved in the regulation of renal response to increased protein level in the diet. Mayfield et al. (1992) demonstrated that a protein-rich diet fed to rats stimulates their kallikrein-kinin system. They observed that this diet or amino acid 
infusion induces both GFR and ERPF increase and also excretion of kinins in urine. Blocking of kinin receptors prevented glomeruli from hyperfiltration. C o r r e a et al. (1992) found the activation of renin-angiotensin system in rats fed a diet with $40 \%$ protein content. They showed an increase in plasma renin activity and mRNA level for renin in kidneys compared with rats receiving $6 \%$ protein diet. Bouby et al. (1990) presume that vasopressin is engaged in renal response to increased protein content in the diet. Pe r v ing et al. (1987) found that GFR increased after glucagon administration and they believe that this is one of the mediators responsible for renal hemodynamic changes due to intake of protein-rich diet or intravenous infusion of amino acids. Nevertheless, Uranga et al. (1989) administered glucagon directly into renal artery of dogs and rats and they did not notice a similar effect. Hostetter (1986) suggested that a protein-rich diet induced changes of the effective filtration pressure, maybe as a result of mesangium growth due to larger protein supply.

In our studies no changes in protein and urea concentrations in plasma were observed in calves receiving a protein-rich diet. However, it does not exclude the existence of renal hemodynamic mechanism, suggested by A lvestrand and Bergstrom (1984) because the stable protein level in peripheral blood does not mean also a stable amino acid concentration in blood of portal vein.

Summing up it can be stated that protein content in the diet is a factor that modifies the renal functions in calves. The larger protein intake increases renal blood and plasma flow and glomerular filtration rate as the expression of the mobilization of adaptation mechanisms. These mechanisms support the efficient excretion of the products of protein catabolism.

In conclusion, enriching the diet with casein caused significant changes in renal functions of young calves. Renal blood and plasma flow, glomerular filtration rate and filtration fraction were increased. Renal hemodynamics changes induced by the protein-rich diet affected first of all the glomerular area as a prerequisite for plasma hyperfiltration. The protein-rich diet did not cause statistically significant changes of total protein and urea concentrations in plasma. There were no significant changes in plasma level of chlorides and plasma osmolality. However, sodium and potassium concentrations in plasma changed significantly.

\section{Vliv zvýšeného množst ví proteinů v dietě na funkci ledvin u telat}

Cílem pokusu bylo ověřit, zda zkrmování diety s vyšším obsahem proteinů telatům v raném postnatálním údobí owlivňuje jejich renální funkce.

Pokus byl vykonán na 10 černostrakatých telatech po narození, a to ve 3 fázích. Dieta pro

2. fázi byla obohacena $25 \%$ kaseinu ve srovnání se standardní dietou, krmenou ve fázích 1 a 3.

Studie renálních funkci zahrnovala metodu clearance ve fázi 1, dále 7 a 14 d po zahájení fáze 2, a 7 d po návratu ke standardní dietě (fáze 3). Jako testovací látky byly použity inulin a PAH.

Rychlost glomerulární filtrace (GFR) a clearance PAH byly definovány podle rychlosti eliminace inulinu a PAH z krvi. Efektivní renální průtok krve (ERPF) a filltrační frakce (FF) byly vypočítány. Koncentrace krevních elektrolytů $\left(\mathrm{Na}^{+}, \mathrm{K}^{+}, \mathrm{Cl}^{-}\right)$, proteinů a urey byly rovněž stanoveny'.

Zvýšené množství proteinů v dietě neovlivnilo celkovou koncentraci proteinů a urey $\mathrm{v}$ krevní plazmě telat. Koncentrace $\mathrm{Na}^{+}$stoupla, $\mathrm{K}^{+}$klesla, zatímco $\mathrm{Cl}^{-}$a osmolalita plazmy se nezměnily. Naproti tomu došlo k signifikantnímu zvýšení GFR a FF. 
Výsledky pokusu ukazují, že př́jem diety s vysokým obsahem proteinů modifikuje renální funkce u telat $v$ raném postnatálním údobí. Sedmidenní zkrmování diety s prídavkem kaseinu zvýšilo průtok krve a plazmy ledvinami a zvýšilo FF. Lze předpokládat, že tyto změny jsou výrazem mobilizace adaptačních mechanizmú pro účinné vychytávání produktů metabolizmu proteinů $\mathrm{z}$ organizmu. Změny renální hemodynamiky indukované vysokoproteinovou dietou zahrnovaly jako první glomerulární oblast jako podmínku pro hyperfiltraci krevní plazmy.

\section{References}

ALVESTRAND. A., BERGSTROM. J. 1984: Glomerular hiperfiltration after protein ingestion, during glucagon infusion and in insulin-dependent diabetes is induced by a liver hormone. Lancet I:195-197

ALVESTRAND. A.. ZIMMERMAN. L.. BERGSTROM. J. 1988: Proteinal role of a liver-divided factor in mediating renal response to protein. Blood 60:276-284

BERGSTROM. J.. AHLBERG. M.. ALVESTRAND. A. 1985: Influence of protein intake on renal hemodynamics and plasma hormone concentration in normal subjects. Actu Med. Scand. 217:189-197

BONETTO. R.. ARANY. E.. DEL CASTILLO. A.. URANGA, J. 1987: Effect of glomerulopressin on several isolated veins and arteries of different species. Acta Physiol. Pharmacol. Latinoam. 37:197-205

BOSCH. J. P.. SACCAGGI. A., LALER. A.. RONZO. C., BELLADONNE. M.. GLABMAN. S. 1983: Renal functional reserve in humans. Effect of protein intake on glomerular filtration rate. Am. J. Med. 75:943-950

BOLBY. N.. TRINH TRANG TAN. M. M.. CONTAND. C.. BANKIR. L. 1990: Vasopressin is involved in renal effects of high-protein diet: study in homozygous Brattleboro rats. Am. J. Physiol. 260:96-100)

BREINEK. P.. BOLDA. J. 1970: A rapid method for the determination of urea using a diacety Imonooxyme. Vet. Lek. 16:186-188

BRENNER. B. M. 1983: Hemodynamically mediated glomerular injury and the progressive nature of kidney disease. Kidney Int. 23:647-655

CORREA. R.. HOSTETTER. T. H., ROSENBERG. M. E. 1992: Effect of dietary protein on renin and angiotensinogen gene expression after renal ablatory. Am. J. Physiol. 262:631-638

DALTON. R. G. 1988: Renal function in neonatal calves - inulin. thiosulphate and para-aminohippuric acid clearance. Br. Vet. J. 124:498-502

GRAF. H. 1983: Effect of amino acid infusion on glomerular filtration rate. N. Eng. J. Med. 308:159-160

HARTMANN. H.. SCHMIETENDORF. L.. DEVAUX. S. 1987: Beziehungen zwischen Durchfallerkrankung und Nierenfunktion bei Kalb. Arch. Exp. Vet. Med. 41:129-137

HIGASHI. A.. PETERS. L. 1970: A rapid colorimetric method for the determination of inulin in plasma and urine. J. clin. Lab. Med. 35:475-485

HOSTETTER. T. H.. MEYER. T. W.. RENNKE. H. G. 1986: Chronic effect of dietary protein in the rat with intact and reduced renal mass. Kidney Int. 30. 1986:509-514

JOLIFFE. A.. S.MITH. W. 1931: The excretion of urine in the dog. The urea and creatinine clearance on cracer meal diet. Am J. Physiol. 99:101-108

LEE. K. E., SUMMERILL. R. A. 1992: Glomerular filtration rate following administration of individual amino acids in conscious dogs. Q. Exp. Physiol. 67:459-465

MAGGIORA. E. M., SILBERSTEIN. C.. ARANY, E. 1991: Enhanced glomerulopressin production and glomerular filtration rate by amino acid infusion in normal humans. Proc. Soc. Exp. Biol. Med. 196:170-174

MAYFIELD, R. K.. JAFFA. A., EDMUNDSON. A. W., HARVEY, J. M. 1992: Renal hyperfiltration states relationship to kallikrein and kinins. Agent. Act. 38:142-144

NAHOA. A. M.. CARPENTIER, J. E.. BASSETT, A. M. 1990: Compensatory renal growth: role of growth hormone and insulin-like growth factor I. Nephrol. Dial. Transplant. 5:123-129

PERVING. H. H.. KEHLET, H.. MOGENSEN. C. E., SVENDESEN. P. A.. HEDING, L. 1987: The effect of short-term glucagon infusion on kidney function in normal man. Diabetologia. 13:323-325

SKRZYPCZAK. W. F. 1989a: Funkcja nerek cieląt w okresie neonatalnym. I. Badania nad zdolnościa do oszczędzania elektrolitów Na, K, Cl, Ca. Mg. P. Pol. Arch. Wet. 29:23-33

SKRZYPCZAK. W. F. 1989b: Funkcja nerek cieląt w okresie neonatalnym. II. Badania nad zdolnością do rozcieńczania i zagąszczania moczu. Pol. Arch. Wet. 29:35-42

SKRZYPCZAK. W. F., BARANOW-BARANOWSKI. S.. JANKOWIAK, D., JANUS, K. 1989: Nerkowy przepływ osocza u cieląt w okresie neonatalnym. Med. Wet. 45:185-187

URANGA. J.. FUENZALIDA, R., RAPOPORT, A. L., DEL CASTILlO. E. 1989: Effect of glucagon and glomerulopressin on the renal function of the dog. Horm. Metab. Res. 11:275-279 
WANGH, W. H., BEALL, P. T. 1974: Simplified measurement of p-aminohippurate and other arylamines in plasma and urine. Kidney. Int. 4:429-433

WANNER, M. M., ZIV, G., NICOLET, J., NOELPP, U. P., ROESLER, H. 1981: Experiments with the double isotope single-injection method for determining glomerular filtration rate and effective renal plasma flow in calves. Res. Vet. Sci. 30: 239-241

Address for correspondence:

Dr Sc. Wiesław F. Skrzypczak

Department of Animal Physiology

University of Agriculture

ul. Doktora Judyma 6

71-466 Szczecin,

Poland 